УДК 94(4); ББК 63.3(4)4+63.3(4)5+68.35; DOI https://doi.org/10.21638/spbu19.2021.202

P. Guzowski

\title{
MILITARY REVOLUTION AND STATE CAPACITY OF JAGIELLONIAN STATES AT THE TURN OF THE MIDDLE AGES IN EUROPEAN CONTEXT
}

The Later Middle Ages saw the beginning of a fundamental transformation of the state treasury, from the model in which state revenue was derived mainly from royal domains, to one in which the major source of revenue was taxes ${ }^{1}$. Previous studies have emphasized that the military revolution was one of the crucial factors triggering this fiscal transformation. Military historians have studied the beginnings of the revolution, focusing on modernization of warfare techniques, tactics, and organization of the army. Financial historians have concentrated their attention mainly on western and southern European states as precursors to change ${ }^{2}$, whereas the evolution from domain state to tax state in central and eastern Europe has been much less explored ${ }^{3}$. Although considerable research has been devoted to the

${ }^{1}$ Parker G. The Military revolution: Military innovation and the rise of the West, 1500-1800. Cambridge, 1988; Tilly C. Coersion, capital and European states, AD 990-1990. Oxford, 1990; Bonney R., Ormrod W. M. Crises, revolutions and self-sustained growth: Toward a conceptual model in fiscal history // Crises, revolutions and self-sustained growth: Toward a conceptual model in fiscal history: Essays in European fiscal history, 1130-1830. Stamford, 1999. P. 1-21; Glete J. War and the state in Early Modern Europe. Spain, the Dutch Republic and Sweden as fiscal-military states, 1500-1660. London, 2002; O'Brien P. K. Fiscal and financial preconditions for the formation of developmental states in the West and East from the Conquest of Ceuta (1415) to the Opium War (1839)// Journal of World History. 2012. Vol. 23. No. 3. P. 513-553; Karaman K. K., Pamuk S. Different paths to modern state in Europe: The interaction between warfare, economic structure and political regime // American Political Science Review. 2013. Vol. 107. No. 3. P. 603-626.

${ }^{2}$ Economic systems and state finance. The origins of the modern state in Europe $13^{\text {th }}$ to $18^{\text {th }}$ centuries. Oxford, 1995; Crises, revolutions and self-sustained growth: Toward a conceptual model in fiscal history: Essays in European fiscal history, 1130-1830. Stamford, 1999; The rise of the fiscal state in Europe c. 1200-1815. Oxford, 1999; The rise of fiscal states: A global history, 1500-1914. Cambridge, 2012.

${ }^{3}$ For the evolution in Poland, see: Myśliwski G. From feudal rents towards a tax system in central Europe // La fiscalità nell'economia europea secc. XIII-XVIII = Fiscal systems in the European

(C) P. Guzowski, 2021

$\overline{\text { 2021. № } 2 \text { (30). Июль-Декабрь }}$ 
history of state revenue in the Kingdom of Poland, the Grand Duchy of Lithuania and the Polish-Lithuanian Commonwealth ${ }^{4}$, rather less attention has been paid to the problem of financial crises as a factor leading to institutional reforms ${ }^{5}$. The purpose of this article is to provide an overview of the financial situation of the Kingdom of Poland and the Grand Duchy of Lithuania at the turn of the Middle Ages, when both countries were ruled by members of the Jagiellonian dynasty. Military conflicts engaging the Kingdom and the Duchy in the $15^{\text {th }}$ and especially in the $16^{\text {th }}$ century were a catalyst for institutional and treasury reforms affecting crown/ducal domains and fiscal systems in both states. The reforms were aimed primarily at increasing the royal and ducal revenues, but in the long run they were conducive to political changes, the most important of which was the parliamentary union in 1569 and establishment of the Polish-Lithuanian Commonwealth. Although there were many different sources of royal/ducal revenue, my attention focuses on two whose role in state transformation was of particular importance. For the purposes of this article, the royal domain is understood in a narrow sense as lands/estates belonging to the crown, without royal monopolies, such as mints or salt mines, or customs duties, which still require historical examination. Taxation system is understood here as a system of ordinary and extraordinary land taxes paid by villagers as well as the inhabitants of townlets and towns. In this study, the city tax (Pol. szos) is not included as it was of very little importance from the point of view of the treasury.

\section{THE ROYAL DOMAIN AND TAXATION SYSTEM ON THE ACCESSION OF VLADISLAV Jagiello}

Anna Sucheni-Grabowska, a prominent scholar in the history of Polish state revenue, wrote: «Casimir the Great was not only the last Polish hereditary monarch in the strict sense, but also the last successor who governed his land as he wished ${ }^{6}$. According to Zdzisław Kaczmarczyk,

economy from the $13^{\text {th }}$ to the $18^{\text {th }}$ centuries. Firenze, 2008. P. 270-278; Filipczak-Kocur A. PolandLithuania before Partition // The rise of the fiscal state in Europe c. 1200-1815. Oxford, 1999. P. 443-480; Boroda K., Guzowski P. From King's finance to public finance: Different strategies of fighting financial crisis in the Kingdom of Poland under Jagiellonian Rule (1386-1572) // Le crisi finanziarie: gestione, implicazioni sociali e conseguenze nell'età preindustriale: selezione di ricerche $=$ The financial crises: Their management, their social implications and their consequences in pre-industrial times: Selection of essays. Firenze, 2016. Р. 451-470.

${ }^{4}$ Доўнар-Запольскі М. Дзяржауная гаспадарка Вялікага княства Літоускага пры Ягелонах. Мінск, 2009; Rutkowski J. Skarbowość polska za Aleksandra Jagiellończyka // Kwartalnik Historyczny. 1909. T. 23. Nr 1-2. S. 1-79; Weyman S. Pierwsze ustawy pogłównego generalnego w Polsce (r. 1498, 1520) na tle ówczesnego systemu podatkowego // Roczniki Dziejów Społecznych i Gospodarczych. 1956. T. 18. S. 12-68; Brzeczkowski T. Podatki zwyczajne w Polsce XV wieku // Acta Universitatis Nicolai Copernici. Nauki Humanistyczno-Społecznevo. Historia. T. 18 (128). S. 39-62; Szulc T. 1) Uchwały podatkowe ze szlacheckich dóbr ziemskich za pierwszych dwu Jagiellonów (1386-1501). Łódź, 1991; 2) Organizacja poboru podatków pokoszyckich do połowy XVI wieku // Czasopismo Prawno historyczne. 1988. T. 40. Nr 2. S. 63-83.

${ }^{5}$ Wyczański A. Z dziejów reform skarbowo-wojskowych za Zygmunta I. Próby relucji pospolitego ruszenia // Przegląd Historyczny. 1952. T. 43. Nr 2. S. 287-304; Sucheni-Grabowska A. 1) Monarchia dwu ostatnich Jagiellonów a ruch egzekucyjny. Part 1: Geneza egzekucji dóbr. Wrocław, 1974; 2) Odbudowa domeny królewskiej w Polsce 1504-1548. $2^{\text {nd }}$ ed. Warszawa, 2007; Matuszewski J. Przywileje i polityka podatkowa Ludwika Węgierskiego w Polsce. Łódź, 1983; Boroda K. Kmieć łan czy profit? Co było podstawą poboru łanowego w XV i XVI wieku? // Człowiek wobec miar i czasu w przeszłości. Kraków, 2007. S. 152-170.

${ }^{6}$ Sucheni-Grabowska A. Odbudowa domeny... S. 39. 
Casimir's goal was to «keep the royal domain intact for the future and to increase it at the expense of private property» ${ }^{7}$. Kaczmarczyk estimated that c. 1370 , the crown estates generated about 15,000 marcs of annual income, which accounted for about $21 \%$ of total revenue. This source of revenue was larger than royal mints (10\%), but less important than customs duties $(33 \%)$, salt and lead mines, and other royal monopolies $(36 \%)^{8}$.

Crown estates belonged directly to the king and their management was delegated to starosta, a royal official with judicial and administrative powers in a crown estate in his charge and beyond. Starosta transferred the money income (e. g. rents) from the estate to the royal treasury, whereas rents in kind and fines were a remuneration for his services. Crown estates were also occasionally leased, but the scale of this practice remains unknown ${ }^{9}$.

In his estimation of Casimir the Great's budget, Kaczmarczyk did not include the income from taxes. Although taxes were regularly levied, their rate and character were not recorded, thus they became a subject of historiographic dispute ${ }^{10}$. According to Jacek Matuszewski, the first fixed-rate tax - plough tax (Pol. poradlne) was introduced by Casimir's successor Louis the Hungarian (1370-1382) following the charter of 1374 to the Polish gentry and the charter of 1381 to the clergy. It was a land tax and its rate was 2 groschen per each peasant mansus in noble and ecclesiastical estates and 4 groshen in monastic estates. Matuszewski assumes that the annual income from this tax during the reign of Louis the Hungarian was approximately 8,700 marcs $^{11}$, which was also most probably the amount collected at the beginning of Vladislav Jagiello's reign (1386-1434). Zdzisław Kędzierski's optimistic estimation of Casimir the Great's annual income at the end of his reign is 70,000 marcs. If we add to this the amount obtained from the land tax, the share of this fixed tax in the royal income around the year of Jagiello's accession could be estimated at $11 \%$ of all proceeds.

Neither during the reign of Casimir the Great nor later during the Jagiellonian period did a clear division between the king's private and public revenues develop, although during the $15^{\text {th }}$ and most of the $16^{\text {th }}$ century attempts were made to distinguish between the royal and state sources of income ${ }^{12}$. Eventually, however, the state's needs in the Kingdom of Poland and the Grand Duchy of Lithuania were covered from both sources, so in this article they are treated as one ${ }^{13}$.

\section{Treasury POLICY OF JAgIELlonian RULERS}

The structure of royal revenue established during the reigns of Casimir the Great and Louis the Hungarian differed considerably from the way ducal revenue was organized in the Grand

Kaczmarczyk Z. Monarchia Kazimierza Wielkiego. T. 1: Organizacja państwa. Poznań: Jan Jachowski i Księgarnia Uniwersytecka, 1939. S. 161.

${ }^{8}$ Kaczmarczyk Z. Monarchia Kazimierza Wielkiego... S. 157-202.

${ }^{9}$ Sucheni-Grabowska A. Odbudowa domeny... S. 41.

${ }^{10}$ Grodecki R. Początki pieniężnego skarbu państwowego w Polsce // Wiadomości NumizmatycznoArcheologiczne. 1933. T. 15. S. 1-32; Skwarczyński P. Z badań nad przywilejami ziemskimi budzińskim i koszyckim. Lublin: Towarzystwo Naukowe Katolickiego Uniwersytetu Lubelskiego, 1936; Zgórniak M. Relikty średniowiecznych powinności skarbowych na wsi małopolskiej XVIXVIII wieku. Warszawa, 1959; Matuszewski J. Przywileje i polityka... S. 7-21.

${ }^{11}$ Matuszewski J. Przywileje i polityka... S. 190.

${ }^{12}$ Matuszewski J. Uwagi wprowadzające - początki skarbowości publicznej // Studia z Dziejów Państwa i Prawa Polskiego. 2003. T. 8. S. 9-18.

${ }^{13}$ Senkowski J. Materiały źródłowe do genezy skarbu publicznego w Polsce w Archiwum Głównym Akt Dawnych w Warszawie // Archeion. 1954. T. 23. S. 29-50. 
Duchy of Lithuania. Although the Grand Dukes began minting their own coins in the second half of the $14^{\text {th }}$ century, the level of monetization of Lithuanian economy was much lower than in Poland. Therefore, the vast proportion of Lithuanian dukes' income took the form of dues in kind. The most important was the income generated by ducal estates (where labor was often provided by serfs), followed by war booty, tributes and contributions from conquered and dependent territories ${ }^{14}$. Due to the lack of primary sources, it is, unfortunately, impossible to reconstruct the structure and value of ducal revenue prior to the end of the $15^{\text {th }}$ century. As Lidia Korczak sums up, «Specialists in Lithuanian history agree that prior to the union with Poland, ducal estates provided the economic foundations of the Grand Dukes' power in Lithuania. They were also organically connected with the administrative and territorial structure of the state» ${ }^{15}$. The majority of ducal estates were located in the core of the Grand Duchy of Lithuania - near Vilnius and by the middle Neman River ${ }^{16}$. There were fewer of them in other parts of the Duchy and the conquered Ruthenian territories, but even there «they constituted the economic and human base of central administrative power» ${ }^{17}$. Over the $15^{\text {th }}$ century, ducal estates were used in the development of the system of clientelism in the Grand Duchy of Lithuania, as they were granted or leased to state officials and noblemen in exchange for political support. Although the practice was politically and, at least to some extent, militarily beneficial, it inevitably weakened the role of ducal estates from the point of view of the treasury. Lithuanian gentry was obliged to provide military support (auxilium) to their dukes regardless.

In the Lithuanian taxation system, there were no general and direct taxes, although local taxes were collected, such as pososzczina (in Smolensk Land), podimszczyna (in Kiev Land), wołoszczyna (in Volhynia). Another local tax, serebszczyna, paid in silver coins, was collected in Lithuania proper, Vitebsk Land and Polotsk Land. The charter issued in 1447 by the Grand Duke Casimir Jagiellon, who was at that time preparing for the coronation in the Kingdom of Poland, exempted Lithuanian gentry from serebszczyna as well as from a traditional due in kind known as dziakto. By the end of the $15^{\text {th }}$ century, gentry in other Lithuanian regions was granted exemption from local taxes (pososzczina, podimszczyna, wołoszczyna $)^{18}$. It does not mean, however, that general taxes were not collected in Lithuania. They took the form of extraordinary collection that could only be carried out with the approval of the gentry, which over the following decades led to the establishment of Lithuanian parliament ${ }^{19}$. It can be concluded that the collection of general taxes in the Grand Duchy of Lithuania was an exceptional occurrence and did not play an important role in the ducal budget apart from the years when

${ }^{14}$ Lowmiański H. Studia nad dziejami Wielkiego Ksiestwa Litewskiego. Poznań, 1983. S. 393.

${ }^{15}$ Korczak L. Monarcha i poddani. System władzy w Wielkim Księstwie Litewskim w okresie wczesnojagiellońskim. Kraków, 2008. S. 49.

${ }^{16}$ Wojtkowiak Z. Lithuania transwilniensis saec. XIV-XVI. Podziały Litwy Północnej w późnym średniowieczu. Poznań, 2005.

${ }^{17}$ Korczak L. Monarcha i poddani... S. 51.

${ }_{18}$ Доўнар-Запольскі М. Дзяржауная гаспадарка... С. 567.

19 Любавский М. Литовско-русскій Сеймъ. Опыт по исторіи учрежденія въ связи съ внутреннимъ строемъ и внђшней жизнью государства. М.: Издание Императорского общества истории и древностей российских при Московском университете, 1900. С. 47-150; Kosman M. Parlamentaryzm Wielkiego Księstwa Litewskiego w świetle najnowszych badań // Zapiski Historyczne. 2005. T. 70. Nr 4. S. 91-108; Korczak L. Monarcha i poddani... S. 34-43. 
it took place. With time, the old name serebszczyna came to be used with reference to this general tax ${ }^{20}$. Other sources of income in cash included tributes imposed on towns, customs duties, and rents from inns in ducal estates ${ }^{21}$.

The capacity of crown treasury the Jagiellons found on their arrival in the Kingdom of Poland and the capacity of their own Lithuanian treasury was tested in the times of increased Jagiellonian activity on the international scene and during military conflicts. The level of monetization of the economies of Polish partners and adversaries was considerably higher than that of Lithuanian neighbors, which explains differences between the resources necessary to finance foreign policymaking in the Kingdom and the Grand Duchy. Military conflicts between the Kingdom of Poland and the Teutonic Order, Turkey, the Kingdom of Bohemia, or the Kingdom of Hungary were significantly more costly than the wars fought by the Grand Duchy of Lithuania against Muscovy or purchasing peace from the Tartars.

The expenditure connected with peace-making activities provides examples to illustrate differences between the two countries. When, in 1395, Vladislav Jagiello agreed to settle the debts of his brother-in-law Siemowit IV, Duke of Masovia, amounting to 10,000 marcs of Prague groschen, he most probably used the money currently available in the treasury ${ }^{22}$. In 1404, the king decided to restore Polish control over the Dobrzyń Land by paying 40,000 marcs of Prague groschen to the Teutonic Order. This time the amount was to be derived from an extraordinary land tax, later known as tanowy. Its rate was 10 groschen per mansus, which was five times more than the ordinary land tax (poradlne) ${ }^{23}$. In 1457, Casimir Jagiellon acting in his capacity of the king of Poland bought the Duchy of Oświęcim from its last duke John IV for 50,000 marcs of Prague groschen. Approximately the same sum (80,000 florins) was spent by John I Albert in 1494 to purchase the Duchy of Zator ${ }^{24}$. Both acquisitions were possible, in part, due to the imposition of an extraordinary land tax virtually every year in the 1450 s and every two years in the last decades of the $15^{\text {th }}$ century ${ }^{25}$.

Lithuanian diplomacy required substantially smaller financial resources. The compensation offered in 1444 by Grand Duke Casimir Jagiellon to duke Boleslav IV for abandoning his claim to Drohiczyn Land was only 6,000 marcs of Prague groschen ${ }^{26}$. At the beginning of the $16^{\text {th }}$ century, annual expenditure of the Grand Duchy on maintaining peaceful relations with the Tartars did not exceed 2,500 marcs of Lithuanian groschen ${ }^{27}$.

Military operations required more funds than diplomatic relations. More frequent use of troops recruited specifically for the time of conflict (Pol. wojsko zaciężne), especially during

${ }_{20}$ Доўнар-Запольскі М. Дзяржауная гаспадарка.... С. 569.

${ }^{21}$ Pietkiewicz K. Wielkie Księstwo Litewskie pod rządami Aleksandra Jagiellończyka. Studia nad dziejami państwa i społeczeństwa na przełomie XV i XVI wieku. Poznań, 1995. S. 188-189.

${ }_{22}$ Supruniuk A. Mazowsze Siemowitów (1341-1443). Dzieje polityczne i struktury władzy. Warszawa, 2010. S. 52.

${ }^{23}$ Bieniak J. Kształtowanie się ziemi dobrzyńskiej w średniowieczu // Zapiski Historyczne. 1986. T. 51. Nr 3. S. 37.

${ }^{24}$ Prokop K. R. Księstwa oświęcimskie i zatorskie wobec korony Polskiej w latach 1438-1513. Dzieje polityczne. Kraków, 2002. S. 134-155, 276.

${ }^{25}$ Szulc T. Przeznaczenie a wydatkowane kwot z podatków nadzwyczajnych z dóbr szlacheckich w Polsce w XV wieku // Kwartalnik Historyczny. 1993. T. 100. Nr 2. S. 15-26.

${ }^{26}$ Błaszczyk G. Dzieje Stosunków polsko-litewski. T. II: Od krewa do Lublina. Cz. I. Poznań, 2007. S. 784-787.

${ }^{27}$ Pietkiewicz K. Wielkie Księstwo Litewskie... S. 200. 
the Thirteen Years' War (1454-1466), necessitated the creation of mechanisms for the swift accumulation of essential resources. Rulers resorted to credit in the first place. Kings of Poland, Vladislav Jagiello and Vladislav III, as well as Grand Duke Casimir Jagiellon (later king of Poland) used royal and ducal domains to secure loans from Polish and Lithuanian noblemen. The practice was first introduced in Poland and its scale was greater there than in the Grand Duchy ${ }^{28}$. Loans secured on crown estates were sought by Vladislav Jagiello throughout his reign, but it was during the reign of his son Vladislav III, who needed financial resources to fight the opposition against his accession to the throne of Hungary and to wage wars against Turkey (1440-1444), that the practice of borrowing money became more common (Figure 1). King Casimir Jagiellon's military expenditure connected with his conflict with the Teutonic Order (1454-1466) and the wars over the crowns of Bohemia and Hungary for his sons necessitated further loans. Also during the short reigns of John I Albert and Alexander, when the Kingdom waged a war against Turkey and the Duchy turned against Muscovy, the tendency towards increased pledging of crown and ducal lands continued.

Figure 1. Value of land and other sources of income pledged by Polish kings (in marcs)

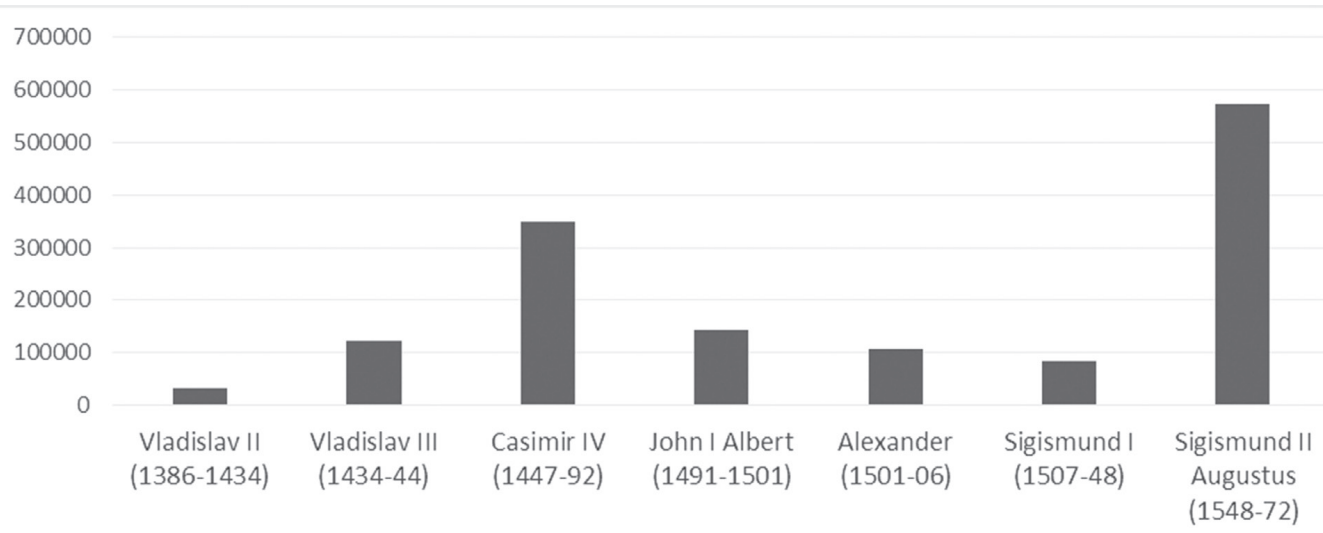

Source: Boroda K., Guzowski P. From King's Finance to Public Finance: Different Strategies of Fighting Financial Crisis in the kingdom of Poland under Jagiellonians Rule (1386-1572) //

Le crisi finanziarie: gestione, implicazioni sociali e conseguenze nell'età preindustriale: selezione di ricerche = The financial crises: their management, their social implications and their consequences in pre-industrial times selection of essays. Firenze, 2016. P. 458.

Short-term benefits in the form of the influx of cash to cover current expenses must be seen in the context of dramatically reduced income from the royal domain at the turn of

${ }^{28}$ Rutkowski J. Skarbowość polska... S. 14-17; Wyczański A. Rozdawnictwo dóbr królewskich za Zygmunta I // Przegląd Historyczny. 1953. T. 44. Nr 3. S. 281-308; Sucheni-Grabowska A. Monarchia dwu ostatnich Jagiellonów... S. 100-142; Sepiat M. Zastaw na dobrach ziemskich i dochodach królewskich w okresie panowania Władysława Warneńczyka na Węgrzech (1440 1444) // Zeszyty Naukowe Uniwersytetu Jagiellońskiego. 1998. T. 79: Prace historyczne. Nr 125. S. 35-49; Guzowski P. Klienci czy wierzyciele? Nie tylko o ekonomicznym wymiarze zastawu dóbr królewskich w pierwszej połowie XV wieku // Patron i dwór. Magnateria Rzeczypospolitej w XVI-XVIII wieku. Warszawa, 2006. S. 67-86. 
the $15^{\text {th }}$ century. In the Kingdom of Poland, crown estates did not provide the treasury with much more than mere 4,000 marcs ${ }^{29}$. Additionally, it is estimated that the total state and royal revenue at that time amounted to approximately 60,000 to 90,000 marcs, of which only 2,500 came from the plough tax (poradlne) ${ }^{30}$. The situation was remedied by extraordinary taxes providing 10,000 marcs of income at most $^{31}$. It can be seen, therefore, that the two sources of income with which this article is concerned did not provide more than 20 to $25 \%$ of total revenue and did so only in the years when extraordinary taxes, approved by parliament, were raised. In the $15^{\text {th }}$ century, the parliament was consulted and gave its approval to extraordinary taxation in $1404,1440,1447,1451,1453,1454,1455,1456,1457 / 58,1459$, $1461,1463,1465,1468,1470,1472,1474,1475,1476,1478,1479,1482,1484,1487,1489$, $1490,1492,1493,1496,1498,1499^{32}$. In years when extraordinary taxes were not collected, the role of income from the domain and ordinary taxes was minimal. After a century of Jagiellonian rule in the Kingdom of Poland, these two important sources of state and royal revenue stopped providing expected income, whereas extraordinary taxation became dependent entirely on parliament's approval.

The situation in the Grand Duchy of Lithuania was different. The total value of ducal revenue was approximately 60,000 sexagenae of Lithuanian groshen, the equivalent of 110,000 marcs in Polish groshen, thus it was comparable to the revenue in the Kingdom of Poland ${ }^{33}$. However, in the second half of the $15^{\text {th }}$ century, the practice of borrowing money secured on ducal land was much less common than in Poland and it is estimated that ducal estates provided $57 \%$ of the total revenue. It is possible that serebszczyna, levied occasionally by the Grand Dukes, also contributed to this amount. It was imposed for the first time by duke Casimir Jagiellon in 1473, but neither the amount obtained nor the area where it was collected are known ${ }^{34}$. It is suggested by some historians that in the $15^{\text {th }}$ century serebszczyna was raised only in ducal estates ${ }^{35}$.

Financial resources at the disposal of Casimir Jagiellon as the Grand Duke of Lithuania and the King of Poland and later resources at the disposal of his sons John I Albert and Alexander allowed for the implementation of polices aimed at territorial and administrative consolidation, especially in the Grand Duchy of Lithuania. Available funds were also sufficient for achieving successes in foreign politics, such as defeating the Teutonic Order or installing Casimir's son Vladislav upon the Bohemian throne. Nevertheless, in European context, Polish and Lithuanian state revenues appear meagre (Figure 2). Jagiellonian rulers' greatest political adversary Matthias Corvinus (d. 1490), king of Hungary and ruler over Silesia and Lusatia, introduced a fiscal reform as a result of which the state annual income reached 600,000 Hungarian florins or c. 12 tones of pure silver, i. e. twice the sum of Polish and Lithuanian state incomes taken together. About $50 \%$ of this amount was derived from ordinary and extraordinary taxation, while only 7-8 \% was generated by the royal domain.

${ }_{29}$ Sucheni-Grabowska A. Odbudowa domeny... S. 59.

${ }^{30}$ Rutkowski J. Skarbowość polska... S. 73; Brzeczkowski T. Podatki zwyczajne... S. 48.

${ }^{31}$ Rutkowski J. Skarbowość polska... S. 72.

${ }^{32}$ Boroda K. Kmieć, łan czy profit... S. 154-158.

${ }^{33}$ Pietkiewicz K. Wielkie Księstwo Litewskie... S. 200.

${ }^{34}$ Доўнар-Запольскі М. Дзяржауная гаспадарка... С. 574.

${ }^{35}$ Pietkiewicz K. Wielkie Księstwo Litewskie... S. 199; Lesmaitis G. Wojsko zaciężne w Wielkim Księstwie Litewskim w końcu XV - drugiej połowie XVI wieku. Warszawa, 2013. S. 138. 
The structure of the state revenue in France was entirely different. The French king had at his disposal 4,700,000 livres tournais (1487), which translated into 94.4 tonnes of silver. Only $2 \%$ of this sum came from the royal domain, while as much as $83 \%$ was derived from $\operatorname{taxes}^{36}$. The structure of the state revenue in other late medieval countries undergoing the processes of centralization resembled that in Jagiellonian states, although the levels of income were incomparably higher. Between 1468 and 1473, the annual income of Charles the Bold of Burgundy was 1,230,000 Flemish pounds (29.5 tonnes of silver), $60 \%$ of which was generated by the ducal domain ${ }^{37}$. In England under Henry VII (c. 1500), more than $50 \%$ of the state revenue of about 110,000 pounds (17 tonnes of silver) was derived from the royal domain ${ }^{38}$.

Figure 2. Value of state revenues in selected European countries at the end of the $15^{\text {th }}$ century (in tonnes of silver)

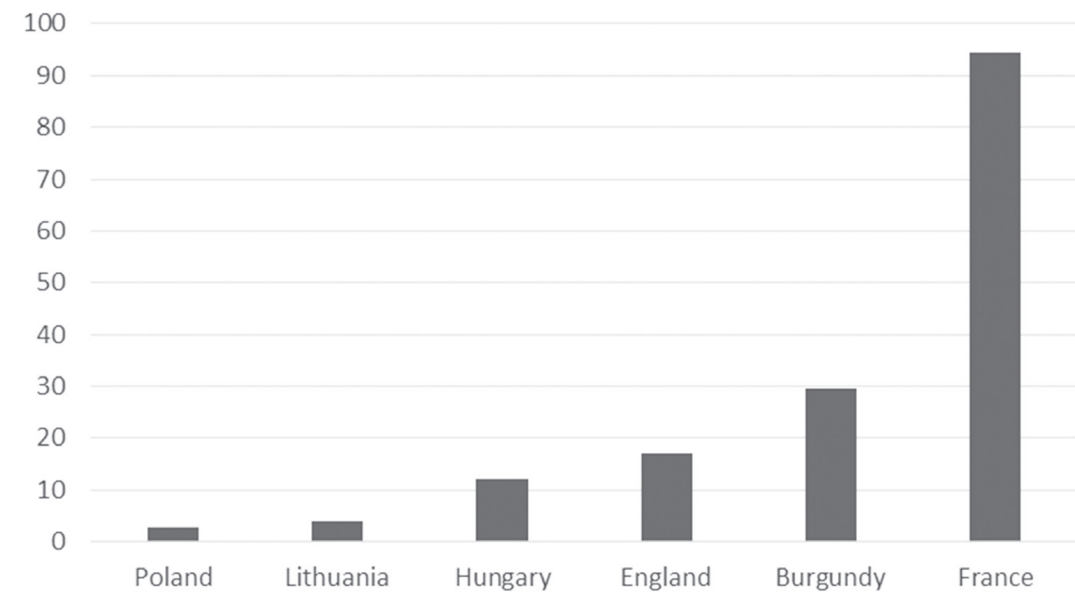

Sources: Rutkowski J. Skarbowość polska za Aleksandra Jagiellończyka // Kwartalnik Historyczny. 1909. T. 23. Nr 1-2. S. 73; Brzeczkowski T. Podatki zwyczajne w Polsce XV wieku // Acta Universitatis Nicolai Copernici. Nauki Humanistyczno-Społecznevo. Historia. T. 18 (128). S. 48; Pietkiewicz K. Wielkie Księstwo Litewskie pod rządami Aleksandra Jagiellończyka. Studia nad dziejami państwa i społeczeństwa na przełomie XV i XVI wieku. Poznań, 1995. S. 200; Grummitt D., Lasslomonie J.-F. Royal public finance

(c. 1290-1523) // Government and Political Life in England and France, c. 1300-1500. Cambridge, 2015. P. 121-122; Stein R. Magnanimous Dukes and Rising States. The Unification of the Burgundian Netherlands, 1380-1480. Oxford, 2017. P. 238; Ormrod W. M. West European Monarchies in the Later Middle Ages // Economic systems and state finance. Oxford, 1995. P. 150-151.

\section{SIXTEENTH-CENTURY REFORMS}

During the reigns of Sigismund I and Sigismund II August, major organizational reforms in the royal/ducal domains and in taxation systems were introduced in the Kingdom of Poland

${ }^{36}$ Grummitt D., Lassalmonie J.-F. Royal public finance (c. 1290-1523) // Government and Political Life in England and France, c. 1300-1500. Cambridge, 2015. P. 121-122.

${ }^{37}$ Stein R. Magnanimous Dukes and Rising States: The Unification of the Burgundian Netherlands, 1380-1480. Oxford, 2017. P. 238.

${ }^{38}$ Ormrod W. M. West European Monarchies in the Later Middle Ages // Economic systems and state finance... P. 150-151. 
and the Grand Duchy of Lithuania. The changes were necessitated by military conflicts between Lithuania and Muscovy (1507-1508, 1512-1522, 1534-1537) as well as Poland and the Teutonic Order (1519-1521), which resulted in financial crises. In the beginning, the crisis forced the king and the duke to seek further loans secured on their domains. In 1514, Sigismund I complained in a letter to the Royal Council that his Lithuanian domain did not bring him any profits ${ }^{39}$; five years later all ducal estates apart from Mogilev were pledged ${ }^{40}$. Eventually, the gradual process of regaining crown and ducal lands began. Loans were repaid, old land leases were revised, and royal/ducal administration over the domain was restored. Later, under the influence of Sigismund I's second wife Bona Sforza, the organizational reform of the royal/ducal domain aimed at increasing its profitability was introduced in the Kingdom as well as the Duchy. Its key element was the Volok Reform of 1557 introduced by Sigismund II August in the Grand Duchy of Lithuania ${ }^{41}$. All these measures resulted in a gradual increase in the level of revenues derived from ducal lands. While in the 1520 s they did not bring almost any income to the treasury, in 1544 they generated 17,500 zlotys ${ }^{42}$, in $1545-22,500$ zlotys $^{43}$, in 1566 it was already as much as 200,000 zlotys ${ }^{44}$. A similar increase was taking place in the Kingdom of Poland. In the 1520s, the crown lands gave 28,000 zlotys, between 1540 and 1548 the sum increased to 65,000 zlotys, and in a decade between 1556 and 1566 to 89,500 zlotys annually ${ }^{45}$.

The maximum level of profits was reached during the years of the First Northern War (1557-1570). The nature of military operations in Livonia with a large number of castles was different from the conflicts with the Crimean Khanate or Muscovy and required raising a professional army, expensive sieges, the organization of permanent garrisons and a permanent field army. Also, the operations in Połock Land required new approaches to warfare and replacing traditional army based on gentry mobilisation by professional military troops. This entailed a drastic increase in the cost of warfare, which even the most radical land reforms were not able to accommodate. This inevitably contributed to increasing fiscal pressure in both Jagiellonian states, where parliaments approved of new extraordinary taxes. It is estimated that in the years 1540-1548 the value of state revenue in the Kingdom ranged from 138,000 to 185,000 zlotys (without income from extraordinary taxes), $34 \%$ of which was the income from crown lands ${ }^{46}$. Extraordinary taxes were imposed at that time every 1.5 year on average. They contributed approximately 50,000 zlotys to the treasury - less than the sum gained from the domain. A more significant increase in the amounts collected in taxes was possible only after broadening the tax base (by abandoning tax exemptions) and raising a land tax rate from 12 to 20 groschen per mansus ${ }^{47}$. These measures resulted in an increase in the state

${ }^{39}$ Sucheni-Grabowska A. Odbudowa domeny... S. 111.

${ }^{40}$ Kolankowski L. Zygmunt August Wielki Książę Litwy do roku 1548. Lwów, 1913. S. 300.

${ }^{41}$ Пичета B. Аграрная реформа Сигизмунда-Августа в Литовско-Русском государстве. М., 1958.

${ }^{42}$ Lithuanian groshen were recalculated into Polish zlotys for the purposes of comparison.

${ }^{43}$ Kolankowski L. Zygmunt August... S. 300.

${ }_{44}$ Доўнар-Запольскі М. Дзяржауная гаспадарка... С. 319.

${ }^{45}$ Sucheni-Grabowska A. Monarchia dwóch ostatnich... S. 95.

${ }^{46}$ Sucheni-Grabowska A. Odbudowa domeny... S. 271.

${ }^{47}$ Patucki W. Reformy skarbowe Sejmu Egzekucyjnego 1562/63 // Studia historyczne. Księga jubileuszowa z okazji 70 rocznicy urodzin dra Stanisława Arnolda. Warszawa, 1965. S. 301-311. 
revenue to 120,000 zlotys in $1563,196,000$ zlotys in $1565^{48}$ and 266,000 zlotys in $1567^{49}$. These amounts were already at least twice as large as the income derived from the domain and soon constituted at least $50 \%$ of all revenues in the Kingdom of Poland.

The situation developed similarly in the Grand Duchy of Lithuania. During the war, tax rates were raised from $12-16$ to $30-48$ groschen and the base-broadening policies were also implemented. In the record year of 1567 , the treasury gained 265,000 zlotys $^{50}$, while 20 years earlier the total income derived from serebszczyna was only 67,500 zlotys ${ }^{51}$.

The cost of military operations in the Northern War exceeded, however, the resources obtained from the reformed royal domain and the modernized tax system (and other sources). For this reason, Sigismund II Augustus resumed the practice of pledging royal/ducal property in exchange for loans from the political elite of the Kingdom of Poland and the Grand Duchy of Lithuania. According to Andrej Januškevič, during the war (1557-1570) Sigismund II August borrowed 500,000 zlotys secured on the Grand Duke's property ${ }^{52}$. In 1564, the Polish parliament also consented to a similar amount of loans secured on royal property. The king did not manage to collect the entire amount because after several years of warfare creditors were more and more difficult to be found. In the end, the royal lands worth 451,000 zlotys were pledged $^{53}$. The monarch borrowed money from Albrecht Hohenzollern, the city of Gdansk, Pomeranian merchants. He also pledged his family silver, but his credit capacity declined over time as the war continued ${ }^{54}$. Even further fiscal reforms introduced in the $16^{\text {th }}$ century, such as the reform of the customs system, or measures aimed at increasing the profitability of the salt monopoly, or growth in income from the Royal Prussia proved insufficient to close the budget gap caused by the war and royal debts would still be repaid long after the end of the conflict ${ }^{55}$.

The exceptional financial effort of the Kingdom of Poland and the Grand Duchy of Lithuania resulted in their ultimate success in the military arena, but it also led to financial crises in both countries ruled by Sigismund II August. This only exposed their inability to cope on their own with the challenges posed by the policies of their neighbors or the international situation. This explains Sigismund's determination in advocating the real union between Poland and Lithuania, which was finally enacted in 1569, and entailed the loss of some Lithuanian territories to the Polish Crown. Unfortunately, one of the conditions of the union was preservation of separate treasury systems. This decision had very significant long-term

${ }^{48}$ Archiwum Główne Akt Dawnych, Archiwum Skarbu Koronnego II. Manuscript 23. C. 1-105.

${ }^{49}$ Archiwum Główne Akt Dawnych, Archiwum Skarbu Koronnego I. Manuscript 112. C. 1-180.

${ }_{50}^{50}$ Доўнар-Запольскі М. Дзяржауная гаспадарка... С. 605; Tyla A. Lietuvos Didžiosios Kunigaikštystès Iždas. XVI Amžiaus Antroji Pusė - XVII Amžiaus Vidurys. Vilnius, 2012. P. 14-15.

${ }^{51}$ Kolankowski L. Zygmunt August... S. 107, 303-304.

52 Янушкевич А. Ливонская война. Вильно против Москвы. 1558-1570. М., 2013. С. 227.

${ }^{53}$ Chłapowski K. Realizacja reform egzekucji dóbr (1563-1665): Sprawa zastawów królewszczyzn małopolskich. Warszawa, 1984. S. 95-102, 155-161.

${ }^{54}$ Księga ekspedycji kancelarii nadwornej 1559-1572. Materiały do dziejów dworu królewskiego. Kraków, 1997. S. 38, 203; Deresiewicz J. Z przeszłości Prus Królewskich. Skarbowość Prus Królewskich od r. 1466-1569. Poznań: Księgarnia Akademicka, 1947. S. 167.

${ }^{55}$ Rybarski $R$. 1) Handel i polityka handlowa Polski w XVI stuleciu. T. 1. Poznań: Towarzystwo Miłośników Miasta Poznania, 1928. S. 295-310; 2) Wielickie żupy solne w latach 1497-1594. Warszawa: Skład główny Domu Książki Polskiej, 1932; Deresiewicz J. Z przeszłości Prus Królewskich... S. 63-179; Keckowa A. Żupy krakowskie w XVI-XVIII wieku. Wrocław, 1969. 
consequences. In the now territorially expanded Kingdom of Poland, regular imposition of extraordinary taxes was preserved throughout the $16^{\text {th }}$ century and in wartime (the Northern War), tax base was broadened and rates were raised. It was resolved in the act of union that the parliament should retain its right to approve of all fiscal decisions made by the king. A new element of particular importance for the treasury was a small but permanent special fund set aside for specific public purposes. The fund consisted of money earned by the royal domain. One-fifth of the income generated by crown lands was used to pay for the maintenance of troops stationed at the border between the Crown and the Crimean Khanate. The parliament controlled the royal domain regularly (once every five years), which made resource forecasting easier and more reliable ${ }^{56}$. Similar reforms were not introduced in the territories of the Grand Duchy. The Northern War devastated the Duchy's finances, but that did not lead to the introduction of measures such as revision of ducal estates, establishment of permanent taxation or more frequent imposition of extraordinary taxes ${ }^{57}$. State reforms in the Duchy focused on legal and administrative issues: creating new types of courts of justice modelled on the Polish courts (The Second and Third Statutes of the Grand Duchy of Lithuania) or dividing the Duchy into new administrative units.

Figure 3. Value of state revenues in selected European countries in the 1560s (in tonnes of silver)

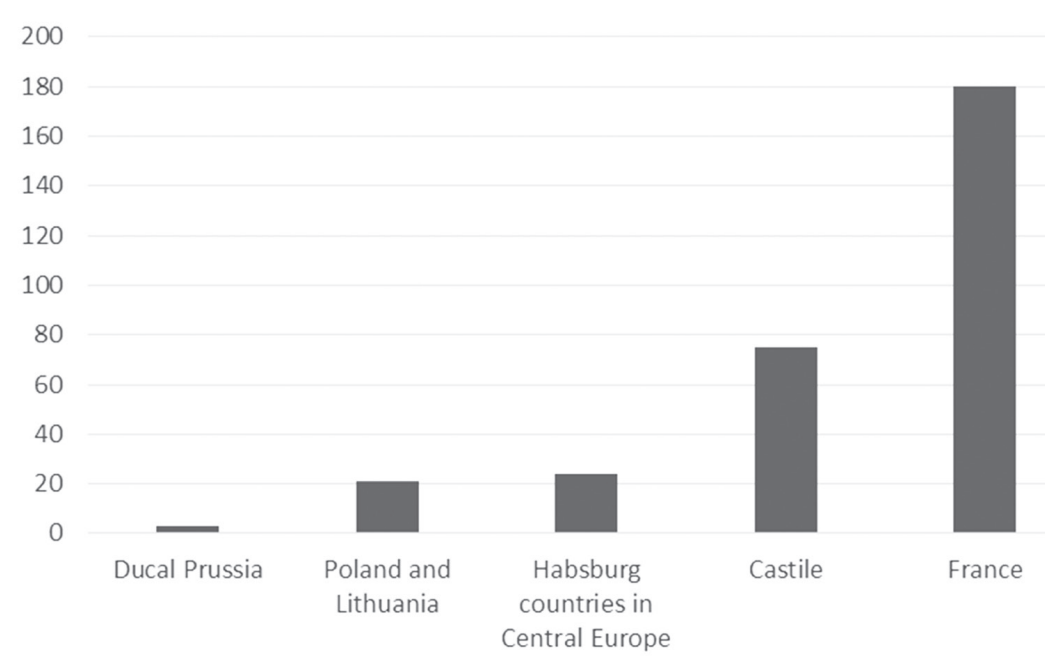

Sources: Guéry A. Les finances de la monarchie française sous l'Ancien Régime // Annales. 1978. Vol. 33. No. 2. P. 227; Gelabert J. Castile, 1504-1808 // The rise of the fiscal state in Europe c. 1200-1815. Oxford, 1999. P. 209; North M. Finances and power in the German state system // The rise of fiscal states: a global history, 1500-1914. Cambridge, 2012. P. 152; Chmelař J. Hospodářská a finanční politika Ferdinanda I. v Čechách (unpublished dissertation written at the Charles University in Prague). 2013. P. 122.

${ }_{56}$ Pawiński A. Skarbowość w Polsce i jej dzieje za Stefana Batorego 1576-1586. Warszawa: Skład Główny w Księgarni Gebethnera i Wolffa, 1881.

${ }^{57}$ Wisner H. Próby utworzenia skarbu stałego w Litwie. Dziejów skarbowości doby Wazów // Kwartalnik Historyczny. 1982. T. 89. Nr 1. S. 85-90; Filipczak-Kocur A. Skarb litewski za pierwszych dwu Wazów 1587-1648. Wrocław, 1994. 
Over the years characterized by the highest increases in tax revenue, cumulated financial resources of the Kingdom of Poland and the Grand Duchy of Lithuania amounted to as much as $800,000-900,000$ zlotys (or about 20 tonnes of silver). In the 1560 s, that was sufficient to ensure military successes in the east, but it would not have sufficed had the PolishLithuanian Commonwealth planned military expansion in the west. Co prawda dochody Albrechta Hohenzolerna wynosiły in Ducal Prussia 200,000 Prussian marks (or 3 tonnes of silver) ${ }^{58}$. Ale Sigismund II August's budget was smaller than that of Ferdinand I Habsburg (Bohemia, Silesia, Hungary and hereditary Austrian lands provided the total annual income of 1,100,000 guldens (or about 24 tonnes of silver) ${ }^{59}$, the latter became the emperor soon and his financial resources rose accordingly. In comparison with other European rulers, PolishLithuanian kings' resources were radically smaller. In the period prior to the crisis caused by religious wars, the income of French kings, calculated in tones of silver, was almost ten times higher than that of Sigismund II August ${ }^{60}$. At the beginning of Philip II's reign, the king derived approximately 542,700,000 maravedi (or 75 tonnes of silver) from Castille ${ }^{61}$, and he also had incomes from Naples, the Netherlands and the New World. Besides, rulers in western and southern Europe had better access to credit on local markets as well as in the largest Italian and German banks.

\section{Информация о статье}

Статья написана в рамках исследовательского проекта Национального научного центра SONATA, contract no. UMO-2016/23/D/HS3/03210 «The military revolution as a modernization factor in the public finance and state organization of the Polish-Lithuanian state in the comparative perspective».

Автор: Guzowski, Piotr - доктор истории, доцент, Центр изучения демографических и экономических структур в доиндустриальной Центральной и Восточной Европе, Университет Белостока, Польша, OrcID 0000-0002-6494-4217; e-mail: guzowski@uwb.edu.pl

Заголовок: Military revolution and state capacity of Jagiellonian states at the turn of the Middle Ages in European context [Военная революция и финансовые возможности Польши и Великого княжества Литовского на рубеже Средневековья и Нового времени на европейском фоне]

Резюме: Целью статьи является знакомство с вопросами финансового положения Королевства Польского и Великого княжества Литовского на рубеже Средневековья и Нового времени. В это время в Европе начинается военная революция, которая не обошла стороной польско-литовское государство. Войны, которые вели обе страны в XV и особенно в XVI в., вынудили провести базовые институциональные и налоговые реформы, касающиеся королевских и великокняжеских владений, а также налоговой системы. Их основной целью было увеличение доходов. Эти действия также привели к ряду политических изменений, наиболее значительным результатом которых стало заключение реального союза (унии) между Польшей и Великим княжеством Литовским в 1569 г. Несмотря на рост доходов и успешную международную политику, налоговые системы в Польше и Литве не были полностью модернизированы. Постоянные налоги играли здесь минимальную роль и позволяли государственному аппарату эффективно функционировать только в мирное время. В свою очередь, кризисные ситуации показали, что кредитоспособность Ягеллонов была очень ограниченной. По сравнению с наиболее развитыми европейскими странами, доходы и финансовые возможности Королевства Польского, а тем более Великого княжества Литовского, можно считать очень скромными.

${ }^{58}$ North M. Finances and power in the German state system // The Rise of Fiscal States: A Global History... P. 152.

${ }^{59}$ Chmelař J. Hospodářská a finanční politika Ferdinanda I. v Čechách (unpublished dissertation written at the Charles University in Prague). 2013. S. 122.

${ }^{60}$ Guéry A. Les finances de la monarchie française sous l'Ancien Régime // Annales. 1978. Vol. 33. No. 2. P. 227.

${ }^{61}$ Gelabert J. Castile, 1504-1808 // The Rise of the Fiscal State in Europe... P. 209. 
Ключевые слова: военная революция, state capacity (финансовые возможности), Ягеллоны, Королевство Польское, Великое княжество Литовское

Литература, использованная в статье:

Доўнар-Запольскі, Мітрафан Віктаравіч. Дзяржауная гаспадарка Вялікага княства Літоускага пры Ягелонах. Мінск: Беларуская навука, 2009. 759 с.

Пичета, Владимир Иванович. Аграрная реформа Сигизмунда-Августа в Литовско-Русском государстве. Москва: Издательство Академии наук СССР, 1958. 548 с.

Янушкевич, Андрей. Ливонская война. Вильно против Москвы. 1558-1570. Москва: Квадрига; Русская панорама, 2013. $381 \mathrm{c}$.

Bieniak, Janusz. Kształtowanie się ziemi dobrzyńskiej w średniowieczu // Zapiski Historyczne. 1986. T. 51. Nr 3. S. 7-45.

Błaszczyk, Grzegorz. Dzieje Stosunków polsko-litewski. T. II: Od krewa do Lublina. Cz. I. Poznań: Wydawnictwo Poznańskie, 2007. 935 s.

Bonney, Richard; Ormrod, William M. Crises, revolutions and self-sustained growth: Toward a conceptual model in fiscal history // Crises, revolutions and self-sustained growth: Toward a conceptual model in fiscal history: Essays in European Fiscal history, 1130-1830 / Ed. by Ormrod, William M.; Bonney, Margaret; Bonney, Richard. Stamford: Shaun Tyas, 1999. P. 1-21.

Boroda, Krzysztof. Kmieć, łan czy profit? Co było podstawą poboru łanowego w XV i XVI wieku? // Człowiek wobec miar i czasu w przeszłości / Red. by Liedke, Marzena; Guzowski, Piotr. Kraków: Avalon, 2007. S. 152-170.

Boroda, Krzysztof; Guzowski, Piotr. From King's finance to public finance: Different strategies of fighting financial crisis in the kingdom of Poland under Jagiellonians Rule (1386-1572) // Le crisi finanziarie: gestione, implicazioni sociali e conseguenze nell'età preindustriale: selezione di ricerche $=$ The financial crises: their management, their social implications and their consequences in pre-industrial times: selection of essays / Ed. by Nigro, Giampiero. Firenze: Firenze University Press, 2016. P. 451-470.

Brzeczkowski, Tadeusz. Podatki zwyczajne w Polsce XV wieku // Acta Universitatis Nicolai Copernici. Nauki Humanistyczno-Społecznevo. Historia. T. 18 (128). 1982. S. 39-62.

Chtapowski, Krzysztof. Realizacja reform egzekucji dóbr (1563-1665). Sprawa zastawów królewszczyzn małopolskich. Warszawa: Państwowe Wydawnictwo Naukowe, 1984. $250 \mathrm{~s}$.

Chmelař, Jiř́. Hospodářská a finanční politika Ferdinanda I. v Čechách (unpublished dissertation written at the Charles University in Prague). 2013. 228 s.

Economic systems and state finance / Ed. by Bonney, Richard. Oxford: Oxford University Press, 1995. 652 p. Filipczak-Kocur, Anna. Poland-Lithuania before partition // The rise of the fiscal state in Europe c. 1200-1815 / Ed. by Bonney, Richard. Oxford: Clarendon Press, 1999. P. 443-480.

Filipczak-Kocur, Anna. Skarb litewski za pierwszych dwu Wazów 1587-1648. Wrocław: Wydawnictwo Uniwersytetu Wrocławskiego, 1994. $120 \mathrm{~s}$.

Gelabert, Juan. Castile, 1504-1808 // The rise of the fiscal state in Europe c. 1200-1815 / Ed. by Bonney, Richard. Oxford: Clarendon Press, 1999. P. 201-241.

Glete, Jan. War and the State in Early Modern Europe. Spain, the Dutch Republic and Sweden as fiscalmilitary states, 1500-1660. London: Routledge, 2002. 304 p.

Grummitt, David; Lassalmonie, Jean-François. Royal public finance (c. 1290-1523) // Government and Political Life in England and France, c. 1300-1500 / Ed. by Fletcher, Christopher; Genet, Jean-Philippe; Watts, John. Cambridge: Cambridge University Press, 2015. P. 116-149.

Guéry, Alain. Les finances de la monarchie française sous l'Ancien Régime // Annales. 1978. Vol. 33. No. 2. P. 216-239.

Guzowski, Piotr. Klienci czy wierzyciele? Nie tylko o ekonomicznym wymiarze zastawu dóbr królewskich w pierwszej połowie XV wieku // Patron i dwór. Magnateria Rzeczypospolitej w XVI-XVIII wieku / Red. Urwanowicz, Jerzy; Dubas Urwanowicz, Ewa; Guzowski, Piotr. Warszawa: Wydawnictwo DiG, 2006. S. $67-86$.

Karaman, Kivanç K.; Pamuk, Şevket. Different paths to modern state in Europe: the interaction between warfare, economic structure and political regime // American Political Science Review. 2013. Vol. 107. No. 3. P. 603-626.

Keckowa, Antonina. Żupy krakowskie w XVI-XVIII wieku. Wrocław: Zakład Narodowy im. Ossolińskich, 1969. $522 \mathrm{~s}$. 
Korczak, Lidia. Monarcha i poddani. System władzy w Wielkim Księstwie Litewskim w okresie wczesnojagiellońskim. Kraków: Historia Iagiellonica, 2008. 207 s.

Kosman, Marceli. Parlamentaryzm Wielkiego Księstwa Litewskiego w świetle najnowszych badań // Zapiski Historyczne. 2005. T. 70. Nr 4. S. 91-108.

Księga ekspedycji kancelarii nadwornej 1559-1572. Materiały do dziejów dworu królewskiego / Red. Kaniewska, Irena. Kraków: Historia Iagiellonica, 1997. 224 s.

Lesmaitis, Gediminas. Wojsko zaciężne w Wielkim Księstwie Litewskim w końcu XV-drugiej połowie XVI wieku / Transl. Piasecka, Beata. Warszawa: Neriton, 2013. 204 s.

Łowmiański, Henryk. Studia nad dziejami Wielkiego Księstwa Litewskiego. Poznań: Wydawnictwo Naukowe UAM, 1983. $579 \mathrm{~s}$.

Matuszewski, Jacek. Przywileje i polityka podatkowa Ludwika Węgierskiego w Polsce. Łódź: Wydawnictwo Uniwersytetu Łódzkiego, 1983. 252 s.

Matuszewski, Jacek. Uwagi wprowadzające — początki skarbowości publicznej // Studia z Dziejów Państwa i Prawa Polskiego. 2003. T. 8. S. 9-18.

Myśliwski, Grzegorz. From Feudal Rents Towards a Tax System in central Europe // La fiscalità nell'economia europea secc. XIII-XVIII = Fiscal Systems in the European Economy from the $13^{\text {th }}$ to the $18^{\text {th }}$ centuries $/$ Ed. by Cavaciocchi, Simonetta. Firenze: Firenze University Press, 2008. P. 270-278.

North, Michael. Finances and power in the German state system // The Rise of Fiscal States: a Global History, 1500-1914 / Ed. by Yun-Casalilla, Bartolomé; O’Brien, Patrick K.; Comin, Francisco. Cambridge: Cambridge University Press, 2012. P. 145-163.

O'Brien, Patrick K. Fiscal and Financial Preconditions for the Formation of Developmental States in the West and East from the Conquest of Ceuta (1415) to the Opium War (1839) // Journal of World History. 2012. Vol. 23. No. 3. P. 513-553.

Ormrod, William Mark. West European Monarchies in the Later Middle Ages // Economic systems and state finance. The origins of the modern state in Europe $13^{\text {th }}$ to $18^{\text {th }}$ centuries / Ed. by Bonney, Richard. Oxford: Oxford University Press, 1995. P. 123-160.

Palucki, Władysław. Reformy skarbowe Sejmu Egzekucyjnego 1562/63 // Studia historyczne. Księga jubileuszowa z okazji 70 rocznicy urodzin dra Stanisława Arnolda. Warszawa: Książka i Wiedza, 1965. S. 301-311.

Parker, Geoffrey. The Military Revolution: Military Innovation and the Rise of the West, 1500-1800. Cambridge: Cambridge University Press, 1988. 234 p.

Pietkiewicz, Krzysztof. Wielkie Księstwo Litewskie pod rządami Aleksandra Jagiellończyka. Studia nad dziejami państwa i społeczeństwa na przełomie XV i XVI wieku. Poznań: Wydawnictwo Naukowe UAM, 1995. $341 \mathrm{~s}$.

Prokop, Krzysztof Rafał. Księstwa oświęcimskie i zatorskie wobec korony Polskiej w latach 1438-1513. Dzieje polityczne. Kraków: Polska Akademia Umiejętności, 2002. 330 s.

The Rise of Fiscal States: a Global History, 1500-1914 / Ed. by Yun-Casalilla, Bartolomé; O’Brien, Patrick K.; Comin, Francisco. Cambridge: Cambridge University Press, 2012. 471 p.

The rise of the fiscal state in Europe c. 1200-1815 / Ed. by Bonney, Richard. Oxford: Clarendon Press, $1999.527 \mathrm{p}$.

Senkowski, Jerzy. Materiały źródłowe do genezy skarbu publicznego w Polsce w Archiwum Głównym Akt Dawnych w Warszawie // Archeion. 1954. T. 23. S. 29-50.

Sepiat, Marcin. Zastaw na dobrach ziemskich i dochodach królewskich w okresie panowania Władysława Warneńczyka na Węgrzech (1440-1444) // Zeszyty Naukowe Uniwersytetu Jagiellońskiego. 1998. T. 79: Prace historyczne. Nr 125. S. 35-49.

Stein, Robert. Magnanimous Dukes and Rising States. The Unification of the Burgundian Netherlands, 1380-1480. Oxford: Oxford University Press, 2017. 315 p.

Sucheni-Grabowska, Anna. Monarchia dwu ostatnich Jagiellonów a ruch egzekucyjny. Cz. 1: Geneza egzekucji dóbr. Wrocław: Zakład Narodowy im. Ossolińskich, 1974. 302 s.

Sucheni-Grabowska, Anna. Odbudowa domeny królewskiej w Polsce 1504-1548. $2^{\text {nd }}$ ed. Warszawa: Muzeum Historii Polski, 2007. 285 s.

Supruniuk, Anna. Mazowsze Siemowitów (1341-1443). Dzieje polityczne i struktury władzy. Warszawa: Wydawnictwo DiG, 2010. $276 \mathrm{~s}$.

Szulc, Tadeusz. Organizacja poboru podatków pokoszyckich do połowy XVI wieku // Czasopismo Prawno historyczne. 1988. T. 40. Nr 2. S. 63-83. 
Szulc, Tadeusz. Przeznaczenie a wydatkowane kwot z podatków nadzwyczajnych z dóbr szlacheckich w Polsce w XV wieku // Kwartalnik Historyczny. 1993. T. 100. Nr 2. S. 15-26.

Szulc, Tadeusz. Uchwały podatkowe ze szlacheckich dóbr ziemskich za pierwszych dwu Jagiellonów (1386-1501). Łódź: Wydawnictwo Uniwersytetu Łódzkiego, 1991. 159 s.

Tilly, Charles. Coersion, Capital and European States, AD 990-1990. Oxford: Oxford University Press, 1990. 269 p.

Tyla, Antanas. Lietuvos Didžiosios Kunigaikštystès Iždas. XVI Amžiaus Antroji Pusė - XVII Amžiaus Vidurys. Vilnius: Nacionalinis Muziejus, 2012. 224 p.

Weyman, Stefan. Pierwsze ustawy pogłównego generalnego w Polsce (r. 1498, 1520) na tle ówczesnego systemu podatkowego // Roczniki Dziejów Społecznych i Gospodarczych. 1956. T. 18. S. 12-68.

Wisner, Henryk. Próby utworzenia skarbu stałego w Litwie. Dziejów skarbowości doby Wazów // Kwartalnik Historyczny. 1982. T. 89. Nr 1. S. 85-90.

Wojtkowiak, Zbysław. Lithuania transwilniensis saec. XIV-XVI. Podziały Litwy Północnej w późnym średniowieczu. Poznań: Wydawnictwo Poznańskie, 2005. 191 s.

Wyczański, Andrzej. Rozdawnictwo dóbr królewskich za Zygmunta I // Przegląd Historyczny. 1953. T. 44. Nr 3. S. 281-308.

Wyczański, Andrzej. Z dziejów reform skarbowo-wojskowych za Zygmunta I. Próby relucji pospolitego ruszenia // Przegląd Historyczny. 1952. T. 43. Nr 2. S. 287-304.

Zgórniak, Marian. Relikty średniowiecznych powinności skarbowych na wsi małopolskiej XVI-XVIII wieku. Warszawa: Państwowe Wydawnictwo Naukowe, 1959. 112 s.

Information about article

This paper was written as part of a research project funded by the National Science Centre, Poland, SONATA, contract no. UMO-2016/23/D/HS3/03210 «The military revolution as a modernization factor in the public finance and state organization of the Polish-Lithuanian state in the comparative perspective».

Author: Guzowski, Piotr - PhD and habilitation in History, Assistant Professor, Center for the Study of Demographic and Economic Structures in Preindustrial Central and Eastern Europe, University of Białystok, Poland, OrcID 0000-0002-6494-4217; e-mail: guzowski@uwb.edu.pl

Title: Military revolution and state capacity of Jagiellonian states at the turn of the Middle Ages in European context

Summary: This article provides an overview of financial situation in the Kingdom of Poland and the Grand Duchy of Lithuania at the end of the Middle Ages and beginning of the early modern era when both states entered the period of military revolution. Military conflicts engaging the Kingdom and the Duchy in the $15^{\text {th }}$ and especially in the $16^{\text {th }}$ century were a catalyst for institutional and treasury reforms affecting crown/ducal domains and fiscal systems in both states. The reforms were aimed primarily at increasing the royal and ducal revenues, but in the long run they were conducive to political changes, the most important of which was the parliamentary union in 1569 and establishment of the Polish-Lithuanian Commonwealth. Although revenues increased and foreign policies of Jagiellonian states proved successful, their treasury systems were never fully modernized. Fixed taxes played a minimal role and allowed the state apparatuses to function relatively efficiently only during periods of peace. The crises, in turn, showed that the Jagiellons' credit capacity was very limited. Compared to the most developed European countries, the revenue and financial capacity of the Kingdom of Poland, and even more so of the Grand Duchy of Lithuania, can be considered very modest.

Keywords: military revolution, state capacity, the Jagiellons, the Kingdom of Poland, the Grand Duchy of Lithuania

References:

Bieniak, Janusz. Kształtowanie się ziemi dobrzyńskiej w średniowieczu [The formation of Dobrzyń land in the Middle Ages], in Zapiski Historyczne. 1986. Vol. 51. No. 3. Pp. 7-45. (in Polish).

Błaszczyk, Grzegorz. Dzieje Stosunków polsko-litewski. T. II: Od krewa do Lublina [History of PolishLithuanian Relations. Vol. 2: From Krewo to Lublin]. Part I. Poznan: Wydawnictwo Poznańskie Publ., 2007. 935 p. (in Polish).

Bonney, Richard (ed.). Economic systems and state finance. Oxford: Oxford University Press, 1995. 652 p. Bonney, Richard (ed.). The rise of the fiscal state in Europe c. 1200-1815. Oxford: Clarendon Press, 1999. $527 \mathrm{p}$.

Bonney, Richard; Ormrod, William M. Crises, Revolutions and Self-Sustained Growth: Toward a Conceptual Model in Fiscal History, in Ormrod, William M.; Bonney, Margaret; Bonney, Richard (eds). Crises, revolutions 
and self-sustained growth: Toward a conceptual model in fiscal history: Essays in European Fiscal history, 1130-1830. Stamford: Shaun Tyas Publ., 1999. Pp. 1-21.

Boroda, Krzysztof. Kmieć, łan czy profit? Co było podstawą poboru łanowego w XV i XVI wieku? [Peasant, field or profit? What was the basis for the land tax in the $15^{\text {th }}$ and $16^{\text {th }}$ centuries], in Liedke, Marzena; Guzowski, Piotr (eds). Człowiek wobec miar i czasu w przeszłości [Man in the face of measures and time in the past]. Cracow: Avalon Publ., 2007. Pp. 152-170. (in Polish).

Boroda, Krzysztof; Guzowski, Piotr. From King's Finance to Public Finance. Different Strategies of Fighting Financial Crisis in the kingdom of Poland under Jagiellonians Rule (1386-1572), in Nigro, Giampiero (ed.). Le crisi finanziarie: gestione, implicazioni sociali e conseguenze nell'età preindustriale: selezione di ricerche = The financial crises: Their management, their social implications and their consequences in pre-industrial times: Selection of essays. Firenze: Firenze University Press, 2016. Pp. 451-470.

Brzeczkowski, Tadeusz. Podatki zwyczajne w Polsce XV wieku [Ordinary taxes in Poland in the $15^{\text {th }}$ century], in Acta Universitatis Nicolai Copernici. Nauki Humanistyczno-Społecznevo. Historia. Vol. 18 (128). 1982. Pp. 39-62. (in Polish).

Chłapowski, Krzysztof. Realizacja reform egzekucji dóbr (1563-1665): Sprawa zastawów królewszczyzn matopolskich [Implementation of reforms in the execution of royal lands (1563-1665): The case of pledges of the royal lands of Lesser Poland]. Warsaw: Państwowe Wydawnictwo Naukowe Publ., 1984. 250 p. (in Polish). Chmelař, Jiří. Hospodářská a finančni politika Ferdinanda I. v Čechách [Economic and financial policy of Ferdinand I in Bohemia] (unpublished dissertation written at the Charles University in Prague). 2013. 228 p. (in Czech).

Downar-Zapolski, Mitrafan Viktaravich. Dzyarzhaunaya gaspadarka Vyalikaga knyastva Litouskaga pry Yagelonakh [State Economy of the Grand Duchy of Lithuania under Jagiellonians]. Minsk: Belaruskaya navuka Publ., 2009. 759 p. (in Belorussian).

Filipczak-Kocur, Anna. Poland-Lithuania before partition, in Bonney, Richard (ed.). The rise of the fiscal state in Europe c. 1200-1815. Oxford: Clarendon Press, 1999. Pp. 443-480.

Filipczak-Kocur, Anna. Skarb litewski za pierwszych dwu Wazów 1587-1648 [Lithuanian Treasury for the first two Vasa 1587-1648]. Wroclaw: Wydawnictwo Uniwersytetu Wrocławskiego Publ., 1994. 120 p. (in Polish). Gelabert, Juan. Castile, 1504-1808, in Bonney, Richard (ed.). The rise of the fiscal state in Europe c. 1200-1815. Oxford: Clarendon Press Publ., 1999. Pp. 201-241.

Glete, Jan. War and the State in Early Modern Europe. Spain, the Dutch Republic and Sweden as fiscalmilitary states, 1500-1660. London: Routledge Publ., 2002. 304 p.

Grummitt, David; Lassalmonie, Jean-François. Royal public finance (c. 1290-1523), in Fletcher, Christopher; Genet, Jean-Philippe; Watts, John (eds). Government and Political Life in England and France, c. 1300-1500. Cambridge: Cambridge University Press, 2015. Pp. 116-149.

Guéry, Alain. Les finances de la monarchie française sous l'Ancien Régime [in English], in Annales. 1978. Vol. 33. No. 2. Pp. 216-239. (in French).

Guzowski, Piotr. Klienci czy wierzyciele? Nie tylko o ekonomicznym wymiarze zastawu dóbr królewskich w pierwszej połowie XV wieku [Clients or creditors? Not only about the economic dimension of the pledge of royal goods in the first half of the $15^{\text {th }}$ century], in Urwanowicz, Jerzy; Dubas Urwanowicz, Ewa; Guzowski, Piotr (eds). Patron i dwór. Magnateria Rzeczypospolitej w XVI-XVIII wieku [Patron and court. Magnates of the Polish-Lithuanian Commonwealth in the $16^{\text {th }}-18^{\text {th }}$ century]. Warsaw: Wydawnictwo DiG Publ., 2006. Pp. 67-86. (in Polish).

Kaniewska, Irena (ed.). Księga ekspedycji kancelarii nadwornej 1559-1572. Materiaty do dziejów dworu królewskiego [Book of the expedition of the court office 1559-1572. Materials to the history of the royal court]. Cracow: Historia Iagiellonica Publ., 1997. 224 p. (in Latin, German, Polish).

Karaman, Kivanç K.; Pamuk, Şevket. Different paths to modern state in Europe: the interaction between warfare, economic structure and political regime, in American Political Science Review. 2013. Vol. 107. No. 3. Pp. 603-626.

Keckowa, Antonina. Żupy krakowskie w XVI-XVIII wieku [Cracow salt mines in the $16^{\text {th }}-18^{\text {th }}$ centuries]. Wroclaw: Zakład Narodowy im. Ossolińskich Publ., 1969. 522 p. (in Polish).

Korczak, Lidia. Monarcha i poddani. System władzy w Wielkim Księstwie Litewskim w okresie wczesnojagiellońskim [Monarch and subjects. System of power in the Grand Duchy of Lithuania in the Early Jagiellonian period]. Cracow: Historia Iagiellonica Publ., 2008. 207 p. (in Polish).

Kosman, Marceli. Parlamentaryzm Wielkiego Księstwa Litewskiego w świetle najnowszych badań [The Parliamentary system of the Grand Duchy of Lithuania in the light of recent research], in Zapiski Historyczne. 2005. Vol. 70. No. 4. Pp. 91-108. (in Polish). 
Lesmaitis, Gediminas. Wojsko zaciężne w Wielkim Księstwie Litewskim w końcu XV-drugiej połowie XVI wieku [Professional army in the Grand Duchy of Lithuania at the end of the $15^{\text {th }}$ to second half of the $16^{\text {th }}$ century]. Transl. Piasecka, Beata. Warsaw: Neriton Publ., 2013. 204 p. (in Polish / translation from Lithuanian).

Łowmiański, Henryk. Studia nad dziejami Wielkiego Księstwa Litewskiego [Studies of the history of the Grand Duchy of Lithuania]. Poznan: Wydawnictwo Naukowe UAM Publ., 1983. 579 p. (in Polish).

Matuszewski, Jacek. Przywileje i polityka podatkowa Ludwika Wegierskiego w Polsce [Privileges and tax policy of Louis I of Hungary in Poland]. Lodz: Wydawnictwo Uniwersytetu Łódzkiego Publ., 1983. 252 p. (in Polish).

Matuszewski, Jacek. Uwagi wprowadzające — początki skarbowości publicznej [Introductory notes — the beginnings of public treasury], in Studia z Dziejów Państwa i Prawa Polskiego. 2003. Vol. 8. Pp. 9-18. (in Polish).

Myśliwski, Grzegorz. From Feudal Rents Towards a Tax System in central Europe, in Cavaciocchi, Simonetta (ed.). La fiscalità nell'economia europea secc. XIII-XVIII = Fiscal Systems in the European Economy from the $13^{\text {th }}$ to the $18^{\text {th }}$ centuries. Firenze: Firenze University Press, 2008. Pp. 270-278.

North, Michael. Finances and power in the German state system, in Yun-Casalilla, Bartolomé; O’Brien, Patrick K.; Comin, Francisco (eds). The Rise of Fiscal States: a Global History, 1500-1914. Cambridge: Cambridge University Press, 2012. Pp. 145-163.

O'Brien, Patrick K. Fiscal and Financial Preconditions for the Formation of Developmental States in the West and East from the Conquest of Ceuta (1415) to the Opium War (1839), in Journal of World History. 2012. Vol. 23. No. 3. Pp. 513-553.

Ormrod, William Mark. West European Monarchies in the Later Middle Ages, in Bonney, Richard (ed.). Economic systems and state finance. The origins of the modern state in Europe $13^{\text {th }}$ to $18^{\text {th }}$ centuries. Oxford: Oxford University Press, 1995. Pp. 123-160.

Pałucki, Władysław. Reformy skarbowe Sejmu Egzekucyjnego 1562/63 [Treasury reforms of the Parliament 1562/63], in Studia historyczne. Ksiega jubileuszowa z okazji 70 rocznicy urodzin dra Stanisława Arnolda [History studies. Jubilee book to celebrate the $70^{\text {th }}$ anniversary of the birth of Dr. Stanislaw Arnold]. Warsaw: Książka i Wiedza Publ., 1965. Pp. 301-311. (in Polish).

Parker, Geoffrey. The Military revolution: Military inovation and the rise of the West, 1500-1800. Cambridge: Cambridge University Press, 1988. 234 p.

Picheta, Vladimir Ivanovich. Agrarnaya reforma Sigizmunda-Avgusta v Litovsko-Russkom gosudarstve [Agrarian reform of Sigismund-Augustus in the Lithuanian-Ruthenian state]. Moscow: Academy of Sciences of the USSR Press, 1958. 548 p. (in Russian).

Pietkiewicz, Krzysztof. Wielkie Księstwo Litewskie pod rządami Aleksandra Jagiellończyka. Studia nad dziejami państwa i społeczeństwa na przełomie XV i XVI wieku [Grand Duchy of Lithuania under the rule of Alexander Jagiellon. Studies in the history of the state and society at the turn of the $15^{\text {th }}$ and $16^{\text {th }}$ centuries]. Poznan: Wydawnictwo Naukowe UAM Publ., 1995. 341 p. (in Polish).

Prokop, Krzysztof Rafał. Księstwa oświęcimskie i zatorskie wobec korony Polskiej w latach 1438-1513. Dzieje polityczne [The Duchies of Oświęcim and Zator towards the Polish Crown in the years 1438-1513. Political history]. Cracow: Polska Akademia Umiejętności Publ., 2002. 330 p. (in Polish).

Senkowski, Jerzy. Materiały źródłowe do genezy skarbu publicznego w Polsce w Archiwum Głównym Akt Dawnych w Warszawie [Historical sources for the origins of the public treasury in Poland in the Central Archive of Historical Records in Warsaw], in Archeion. 1954. Vol. 23. Pp. 29-50. (in Polish).

Sepiał, Marcin. Zastaw na dobrach ziemskich i dochodach królewskich w okresie panowania Władysława Warneńczyka na Węgrzech (1440-1444) [Pledges on landed property and royal income during the reign of Vladislav III in Hungary (1440-1444)], in Zeszyty Naukowe Uniwersytetu Jagiellońskiego. 1998. Vol. 79: Prace historyczne. No. 125. Pp. 35-49. (in Polish).

Stein, Robert. Magnanimous Dukes and Rising States. The Unification of the Burgundian Netherlands, 1380-1480. Oxford: Oxford University Press, 2017. 315 p.

Sucheni-Grabowska, Anna. Monarchia dwu ostatnich Jagiellonów a ruch egzekucyjny. Cz. 1: Geneza egzekucji dóbr [The Monarchy of the Last Two Jagiellons and the Execution Movement. Part 1: The Origin of the Recovery of Royal Lands]. Wroclaw: Zakład Narodowy im. Ossolińskich Publ., 1974. 302 p. (in Polish). Sucheni-Grabowska, Anna. Odbudowa domeny królewskiej w Polsce 1504-1548 [Rebuilding the royal domain in Poland 1504-1548]. 2n ed. Warsaw: Muzeum Historii Polski Publ., 2007. 285 p. (in Polish). 
Supruniuk, Anna. Mazowsze Siemowitów (1341-1443). Dzieje polityczne i struktury władzy [Mazovia of Siemowits (1341-1443). Political history and power structures]. Warsaw: Wydawnictwo DiG Pibl., 2010. 276 p. (in Polish).

Szulc, Tadeusz. Organizacja poboru podatków pokoszyckich do połowy XVI wieku [Organization of the collection of taxes from Koszyce priviledge until the middle of the $16^{\text {th }}$ century], in Czasopismo Prawno historyczne. 1988. Vol. 40. No. 2. Pp. 63-83. (in Polish).

Szulc, Tadeusz. Przeznaczenie a wydatkowane kwot z podatków nadzwyczajnych z dóbr szlacheckich w Polsce w XV wieku [The purpose of the amounts spent from extraordinary taxes on noble goods in Poland in the $15^{\text {th }}$ century], in Kwartalnik Historyczny. 1993. Vol. 100. No. 2. Pp. 15-26. (in Polish).

Szulc, Tadeusz. Uchwaty podatkowe ze szlacheckich dóbr ziemskich za pierwszych dwu Jagiellonów (1386-1501) [Tax resolutions from noble landed estates for the first two Jagiellons (1386-1501)]. Lodz: Wydawnictwo Uniwersytetu Łódzkiego Publ., 1991. 159 p. (in Polish).

Tilly, Charles. Coersion, Capital and European States, AD 990-1990. Oxford: Oxford University Press, 1990. 269 p.

Tyla, Antanas. Lietuvos Didžiosios Kunigaikštystès Iždas. XVI Amžiaus Antroji Pusé - XVII Amžiaus Vidurys [Treasury of the Grand Duchy of Lituania. The second half of the $16^{\text {th }}$ Century - the middle of the $17^{\text {th }}$ century]. Vilnius: Nacionalinis Muziejus Publ., 2012. 224 p. (in Lithuannian).

Weyman, Stefan. Pierwsze ustawy pogłównego generalnego w Polsce (r. 1498, 1520) na tle ówczesnego systemu podatkowego [First Resoliution of the General Poll tax in Poland $(1498,1520)$ in the context of the tax system ], in Roczniki Dziejów Spolecznych i Gospodarczych. 1956. Vol. 18. Pp. 12-68. (in Polish).

Wisner, Henryk. Próby utworzenia skarbu stałego w Litwie. Dziejów skarbowości doby Wazów [Attempts to create a permanent treasure in Lithuania. The treasure history of the Vasa era], in Kwartalnik Historyczny. 1982. Vol. 89. No. 1. Pp. 85-90. (in Polish).

Wojtkowiak, Zbysław. Lithuania transwilniensis saec. XIV-XVI. Podziały Litwy Pólnocnej w późnym średniowieczu [Lithuania transwilniensis, $14^{\text {th }}-16^{\text {th }}$ centuries. The divisions of Northern Lithuania in the late Middle Ages]. Poznan: Wydawnictwo Poznańskie Publ., 2005. 191 p. (in Polish).

Wyczański, Andrzej. Rozdawnictwo dóbr królewskich za Zygmunta I [Distribution of royal lands during the reign of Sigismund I], in Przeglad Historyczny. 1953. Vol. 44. No. 3. Pp. 281-308. (in Polish).

Wyczański, Andrzej. Z dziejów reform skarbowo-wojskowych za Zygmunta I. Próby relucji pospolitego ruszenia [History of treasury and military reforms under Sigismund I], in Przeglad Historyczny. 1952. Vol. 43. No. 2. Pp. 287-304. (in Polish).

Yanushkevich, Andrey. Livonskaya voyna. Vil'no protiv Moskvy. 1558-1570 [The Livonian War. Vilnius against Moscow. 1558-1570]. Moscow: Kvadriga Publ.; Russkaya panorama Publ., 2013. 381 p. (in Russian). Yun-Casalilla, Bartolomé; O’Brien, Patrick K.; Comin, Francisco (eds). The Rise of Fiscal States: a Global History, 1500-1914. Cambridge: Cambridge University Press, 2012. $471 \mathrm{p}$.

Zgórniak, Marian. Relikty średniowiecznych powinności skarbowych na wsi małopolskiej XVI-XVIII wieku [Rectifications of medieval treasury duties in the Lesser Poland in the $16^{\text {th }}-18^{\text {th }}$ century]. Warsaw: Państwowe Wydawnictwo Naukowe Publ., 1959. 112 p. (in Polish). 